OPEN ACCESS

Edited by:

Márcia Vanusa Da Silva, Federal University of Pernambuco,

Brazil

*Correspondence:

B. S. Dileep Kumar dileepkumarbs@yahoo.in

S. Nishanth Kumar nishanthctcri@gmail.com

tPresent address: S. R. Aravind, Sharjah Institute for Medical Research, University of Sharjah,

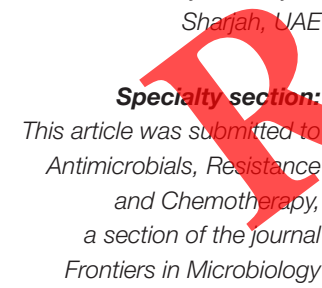

Received: 29 January 2016 Accepted: 08 August 2016 Published: 26 August 2016

Citation:

Nishanth Kumar S, Aravind SR Jacob J, Gopinath G, Lankalapalli RS, Sreelekha TT and Dileep Kumar BS (2016)

Pseudopyronine B: A Potent Antimicrobial and Anticancer Molecule Isolated from a Pseudomonas mosselii. Front. Microbiol. 7:1307. doi: 10.3389/fmicb.2016.01307

\title{
Pseudopyronine B: A Potent Antimicrobial and Anticancer Molecule Isolated from a Pseudomonas mosselii
}

S. Nishanth Kumar ${ }^{1 *}$, S. R. Aravind ${ }^{2 t}$, Jubi Jacob ${ }^{1}$, Geethu Gopinath Ravi S. Lankalapalli', T. T. Sreelekha ${ }^{2}$ and B. S. Dileep Kumar" ${ }^{*}$

${ }_{1}^{1}$ Agroprocessing and Natural Products Division, National Institute for Interdisciplinary Science and Technology - Council of Scientific and Industrial Research, Thiruvananthapuram, India, ${ }^{2}$ Laboratory of Biopharmaceuticals and Nanomedicine, Division of Cancer Research, Regional Cancer Centre, Thiruvananthapuram, India

In continuation of our search for hew bioađtive compounds from soil microbes, a fluorescent Pseudomonas strain isolated from paddy field soil of Kuttanad, Kerala, India was screened for the production of bioactive secondary metabolites. This strain was identified as Pseudomohas mosselii through 16S rDNA gene sequencing followed by BLAST analysis and the bioactive metabolites produced were purified by column chromatography (sifica gel) and a pure bioactive secondary metabolite was isolated. This bioactive compound was identified as Pseudopyronine B by NMR and HR-ESI-MS. Pseudopyronine Brecorded significant antimicrobial activity especially against Grampositive bacteria and agriculturally important fungi. MTT assay was used for finding cell praliferation inhibition, and Pseudopyronine $B$ recorded significant antitumor activity against non-small cell lung cancer cell (A549), and mouse melanoma cell (B16F10). The preliminary MTT assay results revealed that Pseudopyronine B recorded both doseand time-dependent inhibition of the growth of test cancer cell lines. Pseudopyronine B induced apoptotic cell death in cancer cells as evidenced by Acridine orange/ethidium bromide and Hoechst staining, and this was further confirmed by flow cytometry analysis using Annexin $\mathrm{V}$. Cell cycle analysis also supports apoptosis by inducing $\mathrm{G}_{2} / \mathrm{M}$ accumulation in both $\mathrm{A} 549$ and B16F10 cells. Pseudopyronine B treated cells recorded significant up-regulation of caspase 3 activity. Moreover, this compound recorded immunomodulatory activity by enhancing the proliferation of lymphocytes. The production of Pseudopyronine B by P. mosselii and its anticancer activity in A549 and B16F10 cell lines is reported here for the first time. The present study has a substantial influence on the information of Pseudopyronine B from P. mosselii as potential sources of novel drug molecule for the pharmaceutical companies, especially as potent antimicrobial and anticancer agent. 


\section{INTRODUCTION}

The discovery of antibiotics has decreased the spread and severity of a broad range of infectious diseases caused by human pathogenic microbes. However, due to the wide spread use of antibiotics, the competence of many introduced antibiotics in the market is being threatened by the rise of microbial pathogens which are resistance to the current clinical chemotherapeutic agents (Cowan, 1999). Human infections owing to multi-drug-resistant microbes is a serious challenge to many patients, especially those, are in hospitals (Arias and Murray, 2009; Fischbach and Walsh, 2009). Infectious diseases account for more than 13 billion human deaths worldwide, which accounts for about $25 \%$ of all deaths (Zin et al., 2011). The antibiotic treatments of various infectious diseases are also getting limited due to the reemergence of multi-drug-resistance (MDR) pathogenic microbes, which have been frequently reported from many parts of the world. Methicillin-resistant Staphylococcus aureus (MRSA) is one of the important drug resistant pathogen, which is frequently reported by many clinicians worldwide. A part from MRSA and VRSA (vancomycin resistant S. aureus), several other drug resistant and pan-drug-resistant (PDR) microbes especially Gram-negative bacteria, including carbapenem resistant Pseudomonas aeruginosa, Enterococcus faecium, Klebsiella pneumoniae, Acinetobacter baumannii, Enterobacter sp., and Stenotrophomonas maltophilia, are emerging as an important health problem to human being (Huang et al., 2013). Recently, few novel drugs have been industrialized exactly for treating various Gram-negative MDR/PDR bacteria (Payne et al., 2006; Vaara et al., 2010; Velkov et al., 2010). Many bioactive compounds from natural sources have played an important role in the discovery of many antibiotics which are used clinically. Moreover, $70 \%$ of the clinically used antinicrobials are either unchanged natural compounds used directly or derived from natural compounds by synthetic tailoring (Singh et al., 2011). Thus, more investigation should be initiated for diseovering and developing novel antimicrobial molecules especially from natural sources is urgently needed.

At present, one in four deaths in the USA is because of various tumors (Fadeyi et a1., 2013). When classified within age groups, the tumor is one of the five important reasons of death among humans (males and females) and the single major cause of human death around the world (Fadeyi et al., 2013). By 2016, cancer morbidity may increase more than 10 million worldwide. This growing tendency also indicates a shortage in the various current tumor treatments including surgical operation, chemotherapy, and radiotherapy. Since the normal endurance rates of cancer have remained essentially unaffected in spite of such above mentioned hostile treatments, so there is an urgent requirement for new anticancer drugs with advanced efficiency, and fewer side effects that can be developed at a reasonable price to common people worldwide.

Tawiah et al. (2012) reported that "Throughout the various years, natural compounds are the most constantly fruitful basis of diverge bioactive metabolites having several applications in the field of modern human medicine, pharmaceutics and agriculture." Therefore, the search for new antimicrobials from natural sources is an important area of many researchers worldwide. Microorganisms from soils play an important source of many novel antibiotic compounds due to their high abundance and amazing diversity. There are many reports of the production of antimicrobial metabolites by Pseudomonas spp. Some of these antimicrobials have been chemically characterized, and their commercial exploitation is attempted (Zhou et al., 2012).

As mentioned earlier infectious diseases and cancer is the most leading cause of death worldwide. Therefore, novel and potent therapeutic agents are often required to control these diseases. To achieve this goal, several new sources of antimicrobial/anticancer compounds ranging from natural to synthetic are currently being explored worldwide. Therefore in our continuous search for new bioactive secondary metabolites from soil bacteria, Pseudopyronine B was purified from a Pseudomonas mosselii TR strain. The current manuscript also reported the antimicrobial and anticancer activity of Pseudopyromine B.

\section{MATERIALS AND METHODS

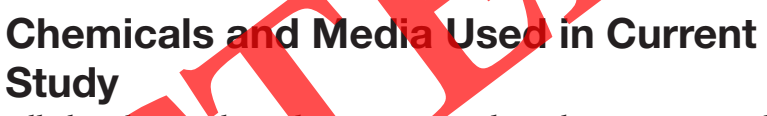

All the chemicals and reagents used in the current study were of the finest purity. All the chemicals used for separation and purification of bioactive compounds were from Merck (Mumbai, India). Silica gel (mesh size: 230-400) used for column purification and precoated silica gel 60 plates $\left(\mathrm{GF}_{254}\right)$ used for thin layer chromatography (TLC) were purchased from Merck (Germany). Various media used for microbiological investigation were purchased from Hi-Media Laboratories Pvt. Ltd, Mumbai, India. The antibiotics ciprofloxacin and amphotericin B, which were used as standard positive control, were procured from Sigma-Aldrich (USA). The Chemsketch Ultra (Toronto, ON, Canada) software was used for drawing the chemical structure.

\section{Bioactive Compound Producing Bacterium}

A fluorescent Pseudomonas, named as TR strain was isolated from paddy field of Kuttanad region of Kerala, India was used in the present study. Kuttanad is a unique agroclimatic zone in India where paddy is cultivated below sea level and is blessed with a rich microbial population which is not fully explored for economic cultivation. The strain was identified as a fluorescent Pseudomonas strain through classical identification methods.

\section{Molecular Identification of TR Strain through 16S rDNA Sequencing Extraction of Bacterial DNA and Sequencing of the $16 S$ Gene}

A pure culture of bacteria was raised in $10 \mathrm{ml}$ of Luria-Bertani broth (LB) for $18 \mathrm{~h}$ to obtain $\mathrm{OD}$ value of approximately 0.7 at $600 \mathrm{~nm}$. The bacterial culture broth $(1.5 \mathrm{ml})$ was pelleted in a microfuge tube for $2 \mathrm{~min}$ at $12,000 \mathrm{rpm}$. Total DNA was extracted using standard phenol-chloroform extraction procedures 
(Sambrook et al., 2001). PCR amplification was done with universal primers (f: 5'-GATTAGATACCCTGGTAGTCCAC-3' and $r$ : $5^{\prime}$-CCCGGGAACGTATTCACCG-3') specific for the $16 \mathrm{~S}$ rDNA gene. The PCR reaction was carried out in a total volume of $50 \mu \mathrm{l}$ [DNA (100 ng), $\mathrm{MgCl}_{2}$ (4 Mm), PCR reaction buffer (1X, Genei, Bangalore, India), each deoxyribonucleotide triphosphate (2.5 mM), Taq polymerase (1.5 U, Genei, Bangalore, India) and each primer ( $40 \mathrm{pmol})$ ]. PCR cycle conditions were: 2 min initial denaturation at $95^{\circ} \mathrm{C}$, followed by 36 cycles of denaturation for $30 \mathrm{~s}$ at $95^{\circ} \mathrm{C}$, followed by $1 \mathrm{~min}$ primer annealing at $60^{\circ} \mathrm{C}$ and 1 min primer extension at $72^{\circ} \mathrm{C}$. Final primer extension step was carried for $2 \mathrm{~min}$ at $72^{\circ} \mathrm{C}$. PCR amplification was achieved on a Bio-Rad Thermal Cycler (USA). Amplicons were analyzed in $1 \%(\mathrm{w} / \mathrm{v})$ agarose gels. The gels were stained with an aqueous solution containing ethidium bromide $(0.5 \mathrm{mg} / \mathrm{mL})$ and visualized on a UV transilluminator. Amplicons were purified using the QIA quick purification kit (Qiagen, Valencia, CA, USA) and sequenced. The sequencing was performed on an ABI PRISM 310 Genetic analyzer (Perkin-Elmer Applied Biosystems, Foster City, CA, USA) using the universal primers (described for PCR amplification) and the Big Dye Terminator Cycle Sequencing Ready Reaction Kit (Perkin-Elmer, Applied Biosystems). The 16S rDNA gene sequences (partial) obtained were finally aligned using ABI Prism software (Perkin-Elmer, Applied Biosystems) and compared to sequences retrieved from GenBank Database and BLAST.

\section{Phylogenetic Analysis}

The phylogenetic investigation was performed using MEGA 6.0 software program (Molecular Evolutionary Genetics Analysis, Version 6.0; Tamura et al., 2007). The phylogenetic tree topologies were assessed by bootstrap analyses based on 1000 replicates, and final phylogenetic trees were constructed with the neighbor-joining method as reported earlier (Saitou and Nei, 1987). The taxonomic position of the present strain was recognized based on $16 \mathrm{~S}$ rDNA homology.

Fermentation and Extraction of Crude Bioactive Secondary Metabolites

The bacterial production and solvent extraction of crude bioactive secondary metabolites from TR strain were done according to George et al. (2015) in King's B media (KB). The supernatant was collected according to the method of George et al. (2015) and extracted with ethyl acetate trice $(1: 1 \mathrm{v} / \mathrm{v})$ in a globe shaped separating funnel $(2 \mathrm{~L})$ and the ethyl acetate portion was collected, concentrated and dried in a Buchi rota evaporator $\left(40^{\circ} \mathrm{C}\right)$ for further detailed investigations.

\section{Purification of Bioactive Compound}

Activated silica gel (230-400 mesh) was filled into a $600 \mathrm{~mm} \times 30 \mathrm{~mm}$ long glass column using n-hexane solvent. The crude secondary metabolite $(0.85 \mathrm{~g})$ was subjected to silica gel column chromatography purification, with a elution profile of 5\% ethyl acetate (EtOAc), 10\% EtOAc, 20\% EtOAc, 40\% EtOAc in hexane $(100 \mathrm{ml}$ each $), 50 \%$ EtOAc in hexane $(150 \mathrm{ml})$, $100 \%$ EtOAc $(100 \mathrm{ml}), 5 \% \mathrm{MeOH}$ in EtOAc $(100 \mathrm{ml})$, obtained 75 fractions. The purity of the fractions was determined by TLC.
An aliquot of each collected fraction was spotted on the activated TLC plates (silica gel $60 ; 10 \mathrm{~cm} \times 10 \mathrm{~cm}$ ). Ethyl acetate and hexane (1:1) was used for developing TLC plates. Spots were positioned by UV and further revealing the TLC plate to iodine vapors. One fraction (tubes 35-37) was obtained as pure. This fraction was evaporated to give a faint white residue $(17 \mathrm{mg})$. Initial bioactivity of this fraction was confirmed by testing against Bacillus subtilis, which was used as indicator test microorganism.

\section{Identification of the Bioactive Compound}

The NMR spectra $\left({ }^{1} \mathrm{H} \mathrm{NMR}\right.$ and $\left.{ }^{13} \mathrm{C}\right)$ of the pure compound were documented using a Bruker DRX500 NMR spectrometer (Bruker, Rheinstetten, Germany) at room temperature and the chemical shifts are reported relative to the corresponding reference solvent (methanol). HR-ESI-MS of the compound was recorded using a Thermo Scientific Exactive Mass Spectrometer (Thermo Fisher 110 Scientific, USA) with an electrospray ionization mode.

\section{Antimicrobial Activity of the Compound Pathogenic Microbes Used in the Study \\ Bacterial}

The following Gram-positive and negative pathogenic bacteria are used for antibacterial study. Gram-positive pathogenic bacteria: B. subtilis (MTCC 2756), Bacillus cereus (MTCC 430), S. aureus (MTCC 902), S. epidermis (MTCC 435), and S. simulans $($ MTEC 3610); Gram-negative pathogenic bacteria: Escherichia coli (MTCC 2622), Klebsiella pneumoniae (MTCC 109), Proteus mirabilis (MTCC 425), Proteus vulgaris (MTCC 1771), P. aeruginosa (MTCC 2642), Salmonella typhi (MTCC 3216), and Vibrio cholerae (MTCC 3905).

\section{Fungal}

The fungal strains used in the present are Aspergillus flavus (MTCC 183), A. fumigatus (MTCC 3376), A. niger (MTCC 282), A. tubingensis (MTCC 2425), Colletotrichum gloeosporioides (MTCC 2151), Fusarium oxysporum (MTCC 284), Penicillium expansum (MTCC 2006), Rhizoctonia solani (MTCC 4634), and Trichophyton rubrum (MTCC 296).

All the test microbes were obtained from MTCC (Microbial Type Culture Collection and GenBank), Council of Scientific and Industrial Research- Institute of Microbial Technology (CSIRIMTECH), Chandigarh, India.

\section{Determining the Antibacterial Activity of Test Compound \\ Minimum Inhibitory Concentration (MIC) and Minimum Bactericidal Concentration (MBC)}

The MIC of the compound was determined according to broth microdilution method as suggested by Clinical and Laboratory Standard Institute, USA (Clinical and Laboratory Standards Institute [CLSI], 2012a). Briefly, the concentration of the fresh overnight culture of test bacteria was adjusted to $1 \times 10^{5} \mathrm{CFU} / \mathrm{ml}$ using a spectrophotometer. Dilutions of inocula were cultured on a Nutrient agar (NA) medium to check the validity of the inoculum and the absence of any contaminations. Different solvent and water dilutions of test compound $(0.5-1000 \mu \mathrm{g} / \mathrm{ml})$ 
and ciprofloxacin $(0.25-250 \mu \mathrm{g} / \mathrm{ml})$ were placed in the wells containing $150 \mu \mathrm{l}$ of nutrient broth (NB), followed by the addition of $10 \mu \mathrm{l}$ of inoculum. After that, the ELISA plates were incubated for $18-24 \mathrm{~h}$ at $37^{\circ} \mathrm{C}$. After incubation MIC was determined by measuring the $\mathrm{OD}$ at $600 \mathrm{~nm}$. The lowest concentration of test compound that produced a significant inhibition (around 90\%) of the growth of the bacteria in comparison with the positive control was identified as the MIC.

About $100 \mu \mathrm{l}$ from the ELISA wells not displaying any microbial growth in the MIC test were diluted serially using $0.85 \%$ saline and plated on NA plates to determine the MBC values. The NA plates were incubated at $37^{\circ} \mathrm{C}$ for $24 \mathrm{~h}$. MBC is defined as the lowest concentration of antibacterial agent that reduces the viability of the initial bacterial inoculum by $99.99 \%$.

\section{Disk Diffusion Experiment of Test Compound}

The antimicrobial activity of the pure compound was performed by the disk diffusion assay against the test bacterial pathogens as mentioned by CLSI, USA (Clinical and Laboratory Standards Institute [CLSI], 2012b). The test bacterial strain preserved in NA at $4^{\circ} \mathrm{C}$ were sub-cultured in $\mathrm{NB}$ to get the working concentration approximately containing $1 \times 10^{6} \mathrm{CFU} / \mathrm{ml}$. The test compound (MIC concentration) was loaded into a sterile disk (Hi-Media) with $6 \mathrm{~mm}$ diameter. Then Mueller-Hinton agar (MHA) plates were swabbed with each test bacterial pathogens and the compound loaded disks were placed along with the control antibiotics disk. Here, ciprofloxacin disks (5 $\mu \mathrm{g} / \mathrm{disk})$ were used as the standard positive control and the plates were incubated for $24 \mathrm{~h}$ at $37^{\circ} \mathrm{C}$ until bacteria had developed in a confluent film. The antimicrobial property of the test compound and antibiotic was determined by measuring the zone of inhibition (diameter) expressed in $\mathrm{mm}$. The experiment was performed in triplicate sets.

\section{Determining the Antifungal Activity of Test Compound} Minimum Inhibitory Concentration

The MIC of test compound against the fungi was done by broth microdilution assay as per the recommendations of Clinical and Laboratory Standard Institute, USA (Clinical and Laboratory Standards Institute [CISI], 2010, 2012c), with RPMI 1640 growth medium supplemented by L-glutamine, without sodium bicarbonate (all from Sigma-Aldrich) and buffered to $\mathrm{pH} 7.0$ according to the previously reported method (Aravind et al., 2014). The lowest concentration of agents that produced a significant inhibition (90\%) of the growth of the test fungi in comparison with the standard positive control was defined as the MIC.

\section{Disk Diffusion Experiment of Test Compound}

The compound was screened for their antifungal activity against test fungi by agar disk diffusion experiment as mentioned by CLSI, USA (Clinical and Laboratory Standards Institute [CLSI], 2008, 2009). Briefly, PDA plates were inoculated (0.1 ml) with a spore suspension in $0.85 \%$ sterile saline. The concentration of test fungal suspension was adjusted to $1 \times 10^{5} \mathrm{CFU} / \mathrm{ml}$ using sterile saline. The test compound (MIC concentrations) was loaded into a 6-mm diameter sterile filter paper disks (Hi-Media, India), air dried and then placed on the surface of the PDA plates swabbed previously by test fungi. The plates were incubated at $35^{\circ} \mathrm{C}$ for 48-72 h. After incubation, the antifungal activity was assessed by measuring the zone of inhibition (diameter) and expressed in millimeter $(\mathrm{mm})$. The assay was performed in triplicate sets.

\section{Anticancer Studies of the Test Compound}

\section{Cancer Cell Lines Used in the Study: Its Source and Maintenance and Treatments}

The following three cancer cell lines were used in the present investigation (1) Non-small cell lung cancer (A549), (2) mouse melanoma cell (B16F10) and (3) liver cancer cell (HepG2) lines and these cell lines were obtained from NCCS (National Centre for Cell Science), Pune, India and maintained throughout the study in Dulbecco's Modified Eagle Medium (DMEM) added with $3 \mathrm{mM}$ of L-glutamine, $100 \mu \mathrm{g} / \mathrm{ml}$ of streptomycin, $100 \mathrm{IU} / \mathrm{ml}$ of penicillin, $10 \%$ heat inactivated $\left(56^{\circ} \mathrm{C}\right)$ fetal bovine serum (FBS) and $25 \mathrm{mM}$ of HEPES [4-(2-hydroxyethyl)-1piperazineethanesulfonic acid]. The final $\mathrm{pH}$ was adjusted to 7.2 by bicarbonate solution at $37 \circ \mathrm{C}$ in a $\mathrm{CO}_{2}$ incubator.

Stock solutions ( $3 \mathrm{mg} / 500 \mathrm{\mu l}$ ) of the test compound, made in dimethyl sulfoxide (DMSO), were further dissolved in the corresponding medium (DMEM) to the necessary working concentrations. A549, B 16F10 and HepG2 cell lines were seeded into ELISA plates and incubated for $24 \mathrm{~h}$ at $37^{\circ} \mathrm{C}$ in a $\mathrm{CO}_{2}$ incubator.After the cell adherence, six different concentrations of est compound $(0.1,1,5,10,50$, and $100 \mu \mathrm{g} / \mathrm{ml})$ were added to the wells containing test cancer cell lines, except to the control wells. Control wells contain only DMEM nutrient medium and the test cells. The cultures were incubated for various time periods (24, 48 , and $72 \mathrm{~h})$.

\section{Anti-proliferative Activity}

The cytotoxic effect of the test compound was determined by MTT [3-(4,5-dimethylthiazol-2-yl)-2,5-diphenyltetrazolium bromide] methods as described earlier (Aravind et al., 2015). The concentrations used in this study are $0.1,1,5,10,50$, and $100 \mu \mathrm{g} / \mathrm{ml}$.

\section{Apoptosis Induction Assay Using the Test Compound \\ Acridine Orange and Ethidium Bromide Staining (AO/EB Staining)}

Apoptotic morphology of cancer cells after treatment with Pseudopyronine B was investigated by staining the cancer cells with a combination of the fluorescent DNA-binding acridine orange $(\mathrm{AO})$ and ethidium bromide $(\mathrm{EB})$ dyes to decide the viable and non-viable cancer cells in a population. Cells were collected and washed three times with PBS after being incubated with $\mathrm{IC}_{50}$ concentration of Pseudopyronine B for 24,48 and $72 \mathrm{~h}$, and were then stained with $100 \mu \mathrm{g} / \mathrm{ml} \mathrm{AO/EB}$ stain (SigmaAldrich) for $2 \mathrm{~min}$. Then the color and structure of the cancer cells were immediately recorded under an inverted fluorescence microscope (Aravind et al., 2014). 


\section{Detection of Morphological Apoptosis with Hoechst 33342 Staining}

The morphological apoptosis like chromatin condensation in the test cancer cell lines was observed by nuclear staining dye Hoechst 33342 (Aravind et al., 2014). After treatment with Pseudopyronine B ( $\mathrm{IC}_{50}$ concentration) for 24,48 and $72 \mathrm{~h}$, the A549 and B16F10 cells were washed with PBS trice and then further fixed with methanol: acetic acid (3:1) for $10 \mathrm{~min}$ at room temperature in the dark. Fixed cells were again washed with PBS and stained with $1 \mu \mathrm{g} / \mathrm{ml}$ of Hoechst 33342 stain $(10 \mathrm{mg} / \mathrm{ml})$ for $10 \mathrm{~min}$ in the dark at room temperature. Changes in the nuclei of cells after staining with Hoechst 33342 were recorded using an inverted fluorescence microscope (stimulation at $350 \mathrm{~nm}$ and emission at $460 \mathrm{~nm}$; Leica, Germany).

\section{Annexin V/Propidium lodide Assay}

The annexin V/propidium iodide (PI) method was done according to the recommendation given by manufacturer's (Invitrogen, USA). Briefly, A549 and B16F10 cell lines were seeded into six well plates and incubated for 24, 48, and $72 \mathrm{~h}$ with Pseudopyronine B ( $\mathrm{IC}_{50}$ concentration). After incubation, the cells were collected and washed with ice-cold PBS and centrifuged. The pellet was resuspended in $100 \mu \mathrm{l}$ of binding buffer containing $2.5 \mu \mathrm{l}$ FITC conjugated Annexin $\mathrm{V}$ and $1 \mu \mathrm{l} 100 \mu \mathrm{l} / \mathrm{ml} \mathrm{PI}$ and incubated for further $15 \mathrm{~min}$ at room temperature in the dark. A total of at least 10000 events were composed and examined by BD flow cytometry (BD Biosciences, San Jose, CA, USA; Liu et al., 2013).

\section{Cell Cycle Analysis of Cancer Cells after Treatment} with Test Compound

The cellular DNA content and distribution in the cell cycle were enumerated by BD flow cytometry using PI staining. A549 and B16F10 cells were seeded in the $\mathrm{T}_{25}$ culture flask and treated with Pseudopyronine $\mathrm{B}$ ( $\mathrm{IC}_{50}$ concentration) for the various time periods $(24,48$, and $72 \mathrm{~h})$. Cells were collected, washed with PBS twice, and fixed in $70 \%$ ethanol at $-20^{\circ} \mathrm{C}$. After fixation, the cells were washed in PBS and centrifuged. The pellets thus obtained was treated with RNase (1 $\mathrm{mg} / \mathrm{ml}$; Roche, Mannheim, Germany) at $37^{\circ} \mathrm{C}$ for $30 \mathrm{~min}$ and then incubated with PI for at least $30 \mathrm{~min}$. Cell-cycle analysis was recorded with the FACS Calibur Flow Cytometer (BD Biosciences, San Jose, CA, USA) and the data were analyzed with Flowjo software.

\section{Determination of Activation of Caspase 3}

Caspase-Glo assay kits (Promega) were used to determine the activation of Caspase 3 by following manufacturer's instructions. A549 and B16F10 cells were plated into ELISA plates and incubated for $24 \mathrm{~h}$. After $24 \mathrm{~h}$ seeding, cells were treated with test compound $(5,10$, and $50 \mu \mathrm{g} / \mathrm{ml})$ and incubated for $48 \mathrm{~h}$. Subsequently, $100 \mathrm{ml}$ of caspase- 3 assay reagent was added to each well. After adding the reagent, the plate was incubated for $1 \mathrm{~h}$ in the dark and the luminescence was quantified with the help of a microplate reader (SpectraMax M5, Molecular Devices). The activity of Caspase was expressed as a percentage (\%) of the untreated control treatment (DMSO). The experiment was performed in triplicate (Wang et al., 2014).

\section{Proliferation Assay of Normal Lymphocytes}

The proliferation of normal lymphocytes when treated with test compound was done as described earlier (Aravind et al., 2014).

\section{Statistical Analysis}

Disk diffusion data was presented as mean \pm standard deviation. The error bars represent \pm SD. taken from three independent experiments. Statistical analysis was performed with SPSS (Version 17.0; SPSS, Inc., Chicago, IL, USA). The significance level was set at $P<0.05$.

\section{RESULTS}

\section{Based on 16S rDNA Sequencing and Phylogenetic Analysis, Bacteria Was Identified as $P$. mosselii}

Molecular characterization of the TR bacterium (P. mosselii) was performed by $16 \mathrm{~S}$ rDNA gene sequencing. PCR amplification of $16 \mathrm{~S}$ rDNA gene yielded $1500 \mathrm{bp}$ amplicon. BLAST analysis recorded $99 \%$ similarity to $P$. Mosselii 165 rDNA sequence accessible in the NCBI GenBank database and based on this our TR strain was identified as $P$. mosselit. The partial $16 \mathrm{~S}$ rDNA gene sequence data have been deposited in the NCBI GenBank nucleotide database under the accession number KF712283. The phylogenetic tree clearly portrayed the relationships our P. mosselii with other Pseudomonas strains used for the present analysis. The present TR bacterial isolate ( $P$. mosselii strain) was very successfully clustered along with other $P$. mosselii sequences obtained from the NCBI GenBank database further confirming the authenticity of our isolate (Figure 1). The P. mosselii was currently deposited in CSIR-IMTECH (Institute of Microbial Technology, Chandigarh, India).

\section{The Bioactive Compound Was Identified as Pseudopyronine B Based on Detailed Spectral Analyses}

Ethyl acetate fraction of $P$. mosselii yielded one main compound, which having an $\mathrm{R}_{\mathrm{f}}$ value 0.68 . Initial bioactivity of this compound was confirmed by testing the antimicrobial activity against $B$. subtilis and the compound recorded significant activity (data not shown). The compound was identified based on the spectral data as Pseudopyronine $\mathrm{B}$ (Figure 2).

Pseudopyronine B: ${ }^{1} \mathrm{H}$ NMR $\left(500 \mathrm{MHz}, \mathrm{CD}_{3} \mathrm{OD}\right) \delta 0.91(2 \times \mathrm{t}$, $J=6.8 \mathrm{~Hz}, 2 \times 3 \mathrm{H}), 1.27-1.39(\mathrm{~m}, 14 \mathrm{H}), 1.42-1.50(\mathrm{~m}, 2 \mathrm{H})$, 1.66 (quin, $J=7.3 \mathrm{~Hz}, 2 \mathrm{H}$ ), $2.38(\mathrm{t}, J=7.5 \mathrm{~Hz}, 2 \mathrm{H}), 2.48$ $(\mathrm{t}, J=7.5 \mathrm{~Hz}, 2 \mathrm{H}), 5.99(\mathrm{~s}, 1 \mathrm{H}) ;{ }^{13} \mathrm{C} \mathrm{NMR}\left(126 \mathrm{MHz}, \mathrm{CD}_{3} \mathrm{OD}\right)$ $\delta 12.9,13.0,22.2,22.3,22.4,26.5,27.5,28.5,28.6,28.8,29.2$, $31.4,31.5,32.9,99.6,102.5,163.7,166.4,167.4$; ESI-MS $[\mathrm{M}+\mathrm{H}]^{+}$ $\mathrm{C}_{18} \mathrm{H}_{31} \mathrm{O}_{3}$ calc'd for $\mathrm{m} / \mathrm{z} 295.22732$, found 295.22729.

\section{Antibacterial Activity of Pseudopyronine B}

The Pseudopyronine B was tested for checking its antibacterial (MIC and MBC) activity against 13 bacterial species using standard CLSI protocol and the values are presented in Table $\mathbf{1 .}$ Pseudopyronine B recorded significant antibacterial activity 


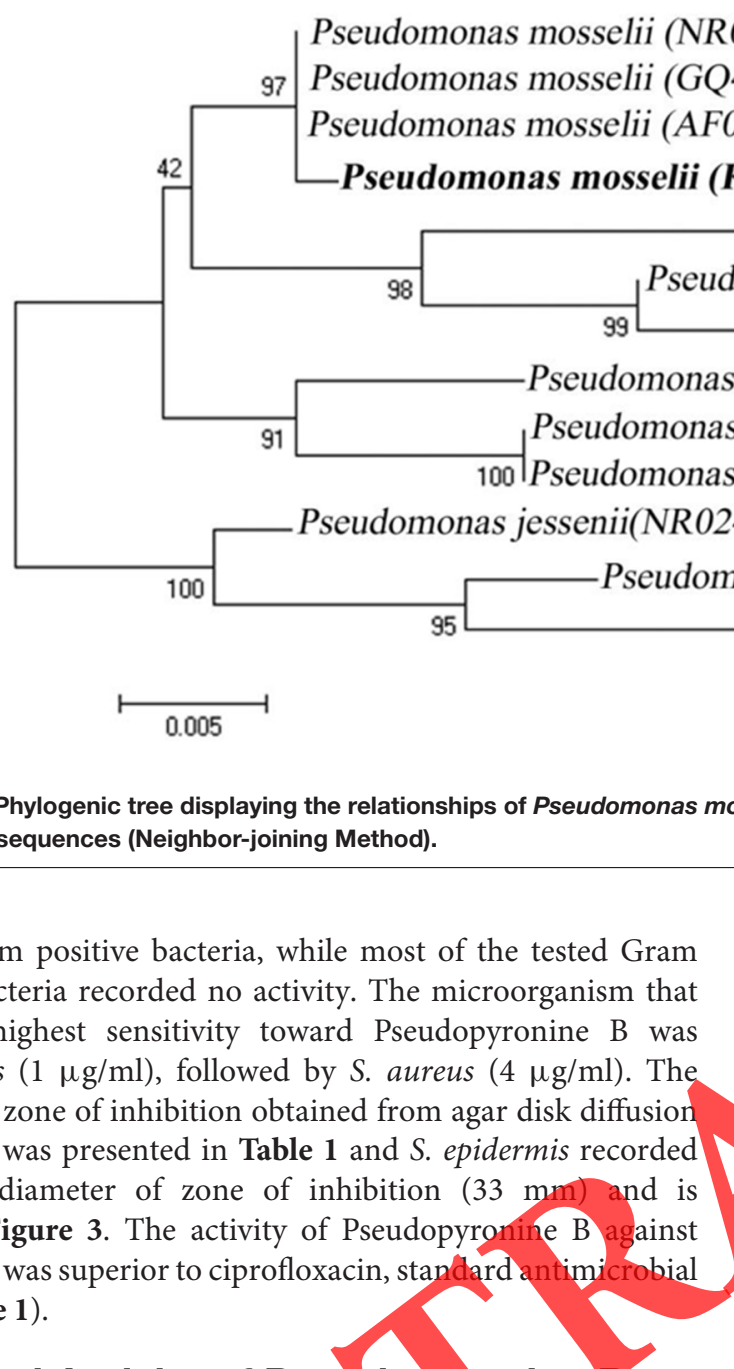

Antifungal Activity of Pseudopyronine $B$

Antifungal property of Psendopyronine $B$ againgt 11 fungi and the MIC values are shown in Table 2. Pseudopyronine B documented good antifungal property especially against plant pathogenic fungi. Pseudopyronine $B$ displayed best MIC value against $P$. expansum $(4 \mu \mathrm{g} / \mathrm{ml})$, followed by $F$. oxysporum and $R$. solani $(16 \mu \mathrm{g} / \mathrm{ml})$. In agar disk diffusion assay $P$. expansum recorded significant activity ( $34 \mathrm{~mm}$; Table 2; Figure 3).

\section{Anticancer Activity}

\section{Pseudopyronine B Recorded Significant}

Anti-proliferative Activity as Evidenced by MTT Assay Anti-proliferative activity of Pseudopyronine B was assessed on non-small cell lung cancer (A549), mouse melanoma cell (B16F10) and liver cancer cell (HepG2) lines. MTT assay was used to evaluate the cell viability after Pseudopyronine $\mathrm{B}$ treatment. From the MTT experiment it is clearly evident that the Pseudopyronine B recorded both dose- and timedependent inhibition in the growth of test cancer cell lines, when treated with 100, 50, 10, 5, 1, and $0.5 \mu \mathrm{g} / \mathrm{ml}$ (Figure 4A). Out of three cell lines tested, A549 and B16F10 cells recorded best activity. A549 and B16F10 cells turned out to be the most sensitive eell lines and were selected for further apoptotic

\section{Apoptotic Induction Assays}

Pseudopyronine B Induces Apoptosis in A549 and B16F10 as Evidenced by Acridine Orange-Ethidium Bromide and Hoechst 33342 Staining

The cultured A549 and B16F10 cells were examined for their morphology features after treatment with Pseudopyronine B. It was observed that the Pseudopyronine $\mathrm{B}$ is inducing characteristic apoptosis features changes such as nuclear condensation, membrane blebbing and formation of apoptotic bodies, when compared to untreated control as evaluated by phase contrast microscope. Moreover, there was a significant reduction in the number of A549 and B16F10 cells after Pseudopyronine B treatment (Figure 4B). Acridine orangeethidium bromide staining was done to confirm the nuclear membrane damage, a characteristic feature of apoptosis as observed by yellow/orange coloration in the nuclei of A549 and B16F10 cells treated with Pseudopyronine B (Figure 5). The cells treated with the compound after 24,48 and $72 \mathrm{~h}$ exhibited time depend increase in AO-EB positivity, when compared to untreated control (Figure 5).

The Hoechst 33342 staining of A549 and B16F10 cells recorded a very significant increase in the number of cancer cells showing nuclear condensation and fragmentation after treatment with Pseudopyronine B when examined through phase contrast microscope (Figure 6). Moreover, cancer cells lost its normal structure after treatment with Pseudopyronine $\mathrm{B}$ and presented an expansion of the endoplasmic reticulum. Some very specific signs of early stages of apoptosis (vacuolization in the cytoplasm, nucleus shrinkage and fragmentation and chromatin densification) can 
A

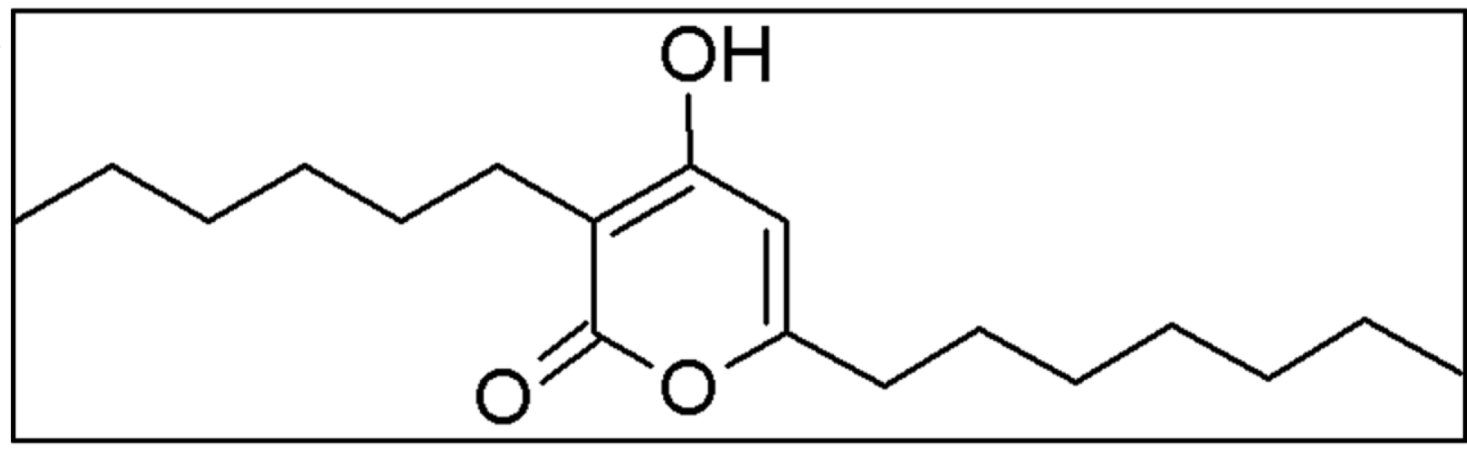

B

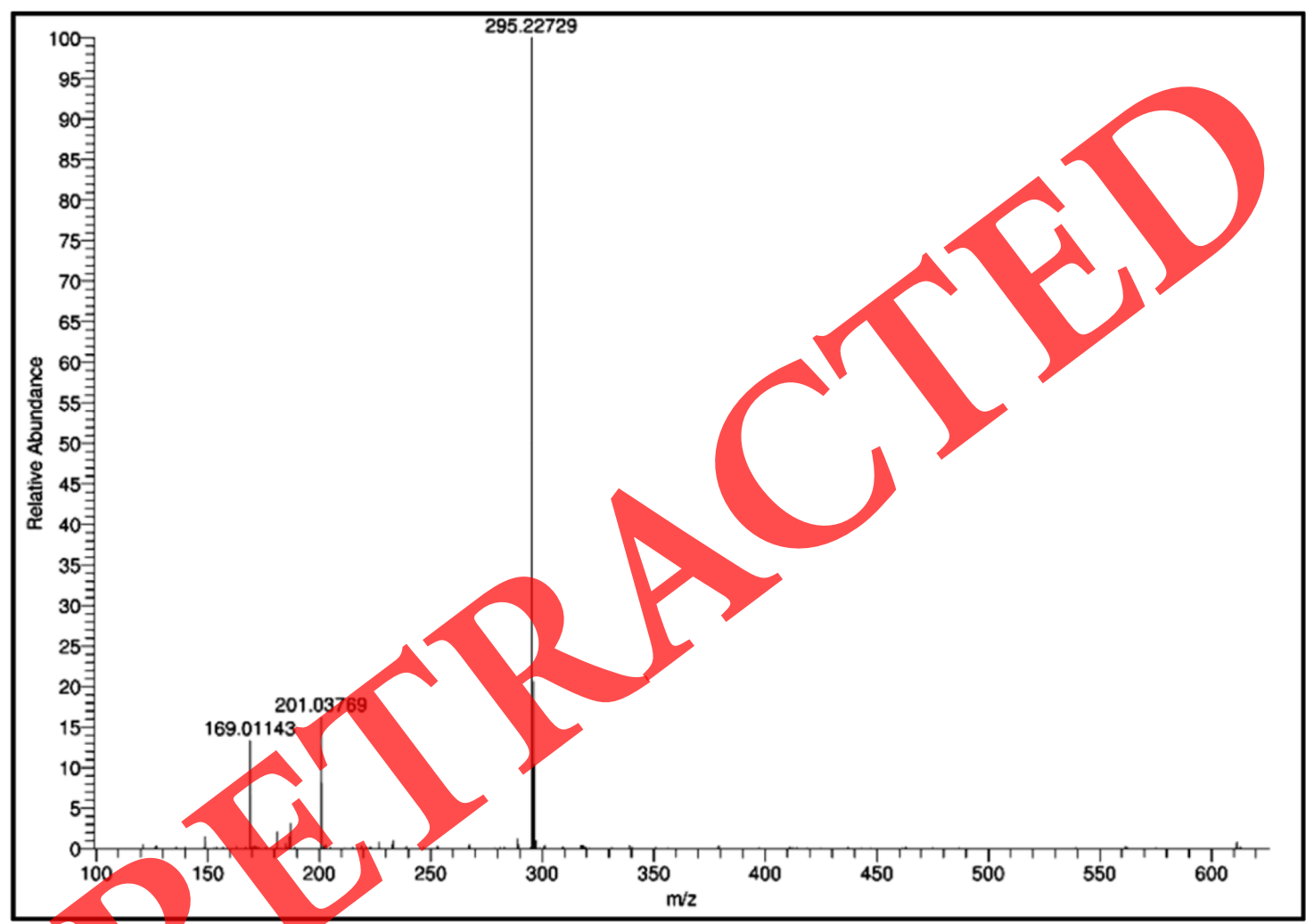

FIGURE 2 | (A) Structure of Pseudopyfonine B and (B) HR-MS spectra of Pseudopyronine B.

also be viewed in Pseudopyronine B treated cells through phase contrast microscope (Figure 6).

\section{Effect of Pseudopyronine B on Cell Cycle Analysis}

Distribution of cells on the different phases of the cell cycle was investigated by flow cytometry after treatment of A549 and B16F10 cells with several concentrations of Pseudopyronine B for 24, 48, and $72 \mathrm{~h}$. In both A549 and B16F10 Pseudopyronine B treated cells, G1 and G2/M phase were increased were as $S$ phases found to be decreased. In A549 cells at $48 \mathrm{~h}$ of incubation control cells possess $68.96 \pm 2.94 \%$ in G1 phase were as in Pseudopyronine B treated cells have $76.36 \pm 2.67 \%$. Control cells in $\mathrm{G} 2 / \mathrm{M}$ phase possess $5.88 \pm 0.84 \%$ were as in Pseudopyronine B treated cells have $11.88 \pm 1.04 \%$. In B16F10 cells at $48 \mathrm{~h}$ of incubation control cells possess $70.62 \pm 3.56 \%$ and $72.79 \pm 3.21 \%$ for Pseudopyronine B treated cells. In G2/M phase control cells possess $17.59 \pm 1.59 \%$ and $21.12 \pm 1.64 \%$ for Pseudopyronine B treated cells suggesting that it can induce significant apoptosis in A549 and B16F10 cells (Figure 7).

\section{Pseudopyronine B Induces Apoptotic Events by Altering Membrane Permeability as Evidenced by Flow Cytometry}

Annexin V-FITC staining, using flow cytometry was used to detect the morphological changes that occur in the early stages of apoptotic cells (Figure 8). After $48 \mathrm{~h}$ of treatment, 
TABLE 1 | Antibacterial activity of Pseudopyronine B.

\begin{tabular}{|c|c|c|c|c|}
\hline \multirow[t]{2}{*}{ Test bacteria } & \multicolumn{3}{|c|}{ Pseudopyronine B } & \multirow[b]{2}{*}{$\begin{array}{c}\text { MIC } \\
(\mu \mathrm{g} / \mathrm{ml})\end{array}$} \\
\hline & $\begin{array}{c}\text { MIC } \\
(\mu \mathrm{g} / \mathrm{ml})\end{array}$ & $\begin{array}{c}\text { MBC } \\
(\mu \mathrm{g} / \mathrm{ml})\end{array}$ & $\begin{array}{l}\text { Zone of inhibition } \\
\text { (Diagram in mm) }\end{array}$ & \\
\hline B. subtilis & 64 & 125 & $20 \pm 1$ & 2 \\
\hline B. cereus & 16 & 32 & $23 \pm 0$ & 1 \\
\hline S. aureus & 4 & 4 & $31 \pm 0.23$ & 1 \\
\hline S. epidermis & 1 & 2 & $33 \pm 0.56$ & 2 \\
\hline S. simulans & 8 & 8 & $28 \pm 1.72$ & 4 \\
\hline E. coli & - & - & - & 1 \\
\hline P. mirabilis & - & - & - & 0.5 \\
\hline P. vulgaris MTCC 1771 & - & - & - & 2 \\
\hline V. cholerae & - & - & - & 2 \\
\hline K. pneumonia & 4 & 8 & 25 & 1 \\
\hline$P$. aeruginosa & - & - & - & 2 \\
\hline S. typhi & 32 & 32 & 22 & 4 \\
\hline
\end{tabular}

Ciprofloxacin

$\begin{array}{cc}\text { MIC } & \text { Zone of inhibition } \\ (\mu \mathrm{g} / \mathrm{ml}) & \text { (Diagram in } \mathrm{mm})\end{array}$

$\begin{array}{ll}2 & 30 \pm 1 \\ 2 & 31 \pm 1.52 \\ 2 & 33 \pm 1.14 \\ 4 & 30 \pm 1.77 \\ 4 & 29 \pm 0.56 \\ 2 & 27 \pm 0.77 \\ 1 & 29 \pm 0.56 \\ 4 & 30 \pm 1.15 \\ 4 & 31 \pm 1.72 \\ 2 & 25 \pm 1.15 \\ 4 & 27 \pm 0 \\ 4 & 29 \pm 1\end{array}$

Pseudopyronine B induced apoptosis on A549 [14.1 $\pm 1.34 \%$ in control to $76.5 \pm 2.97 \%$ in Pseudopyronine $B$ treated cells $(P<0.001)]$ and B16F10 $[21.7 \pm 1.68 \%$ in control to $64.7 \pm 2.67 \%$ in Pseudopyronine B treated cells $(P<0.001)]$ cells.

\section{Pseudopyronine B Induces Caspase 3 Activation in Cells}

Our next attempt was to examine the basic mechanism behind the cytotoxic effect of Pseudopyronine B. For this, we tested the activation of caspase 3 using a colorimetric assay. Pseudopyronine B treated cells and control lysates were prepared and incubated with Ac-DEVD-pNA caspase 3 specific substrate with the reaction buffer and the caspase 3 pNA release was measured using a spectrophotometer at $405 \mathrm{~nm}$. Significant enhancement in the caspase 3 activity was recorded in Pseudopyronine B treated cells when compared with that of control clearly indicating the involvement of caspase 3 in
Pseudopyronine B induced apoptotic cell death (Figure 9). The results are given in Figure 9.

\section{Evaluation of Immunomodulatory Properties of Pseudopyronine B}

Immunomodulatory activity of Pseudopyronine B was checked by the proliferation of lymphocyte. The proliferation lymphocyte was slightly enhanced in Pseudopyronine B treated cells when compared to that of control cells (untreated). The proliferation index of lymphocyte was detected to be 1.08 for $5 \mu \mathrm{g} / \mathrm{ml}$ of pseudopyronine B in the presence of PHA (Figure 10).

\section{DISCUSSION}

The enormous rise in the value of drug discovery and development is a strong encouragement for many pharmaceutical industries to contempt all but the most economically bioactive
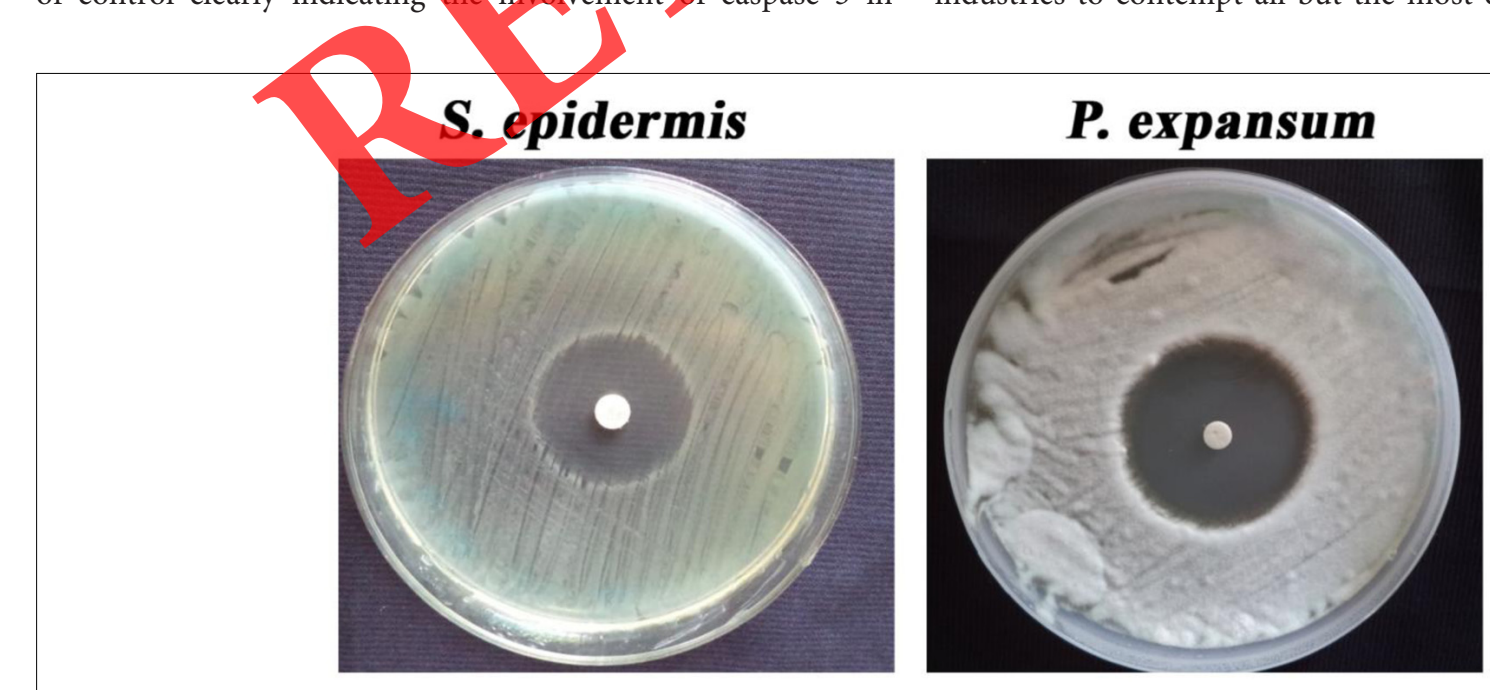

FIGURE 3 | Antimicrobial activity of Pseudopyronine B. 
TABLE 2 | Antifungal activity of Pseudopyronine B.

\begin{tabular}{|c|c|c|c|c|}
\hline \multirow[t]{2}{*}{ Test bacteria } & \multicolumn{2}{|c|}{ Pseudopyronine B } & \multicolumn{2}{|c|}{ Amphotericin B } \\
\hline & $\begin{array}{c}\text { MIC } \\
(\mu \mathrm{g} / \mathrm{ml})\end{array}$ & $\begin{array}{c}\text { Zone of } \\
\text { inhibition } \\
\text { (Diagram in } \mathrm{mm} \text { ) }\end{array}$ & $\begin{array}{c}\text { MIC } \\
(\mu \mathrm{g} / \mathrm{ml})\end{array}$ & $\begin{array}{c}\text { Zone of } \\
\text { inhibition } \\
\text { (Diagram in } \mathrm{mm} \text { ) }\end{array}$ \\
\hline A. flavus & 16 & $21 \pm 0.52$ & 4 & $23 \pm 1.15$ \\
\hline A. fumigatus & 64 & $18 \pm 0.77$ & 2 & $27 \pm 1.72$ \\
\hline A. niger & 32 & $21 \pm 1.12$ & 2 & $26 \pm 0.56$ \\
\hline A. tubingensis & - & - & 4 & $30 \pm 0.77$ \\
\hline C. gloeosporioides & - & - & 32 & $25 \pm 1.12$ \\
\hline F. oxysporum & 16 & $25 \pm 1.12$ & 125 & $26 \pm 2.21$ \\
\hline P. expansum & 4 & $34 \pm 0.52$ & 64 & $23 \pm 2.27$ \\
\hline R. solani & 16 & $24 \pm 1$ & 64 & $23 \pm 072$ \\
\hline T. rubrum & - & - & 2 & $24 \pm 0.56$ \\
\hline
\end{tabular}

-, recorded no activity.

lead molecules (Higginbotham et al., 2013). But, the decreasing quantity of medicines reaching the market is putting strong pressure on the pharmaceutical companies to research and find alternative sources for novel lead molecules (Bennani, 2012). Natural molecules with diverse bioactivity have been used since the beginning of various conventional medicines in early years (Graca et al., 2013). These bioactive molecules are present in all forms of life and are usually produced during the secondary metabolism by almost all organisms. A wide variety of structurally interesting and bioactive secondary metabolites produced by various microorganisms including bacteria, fungi, actinomycetes, etc. have been reported worldwide and many of them are taken by the several pharmaceutical companies as lead drug molecules especially antibiotics (Gao et al., 2012). Several microbes especially from terrestrial soils have an inborn capability of producing many novel natural molecules with various biological properties and this represent rich source of biologically active compounds which may play very important role in drug discovery process for pharma industry (Bode et al., 2002). In the present study, a bacterial strain, named as TR, was isolated from soil during a screening for microbes with potent antimicrobial property. The microbial strain used in the present study was identified as a $P$. mosseli strain based $16 \mathrm{~S}$ rDNA sequencing and BLAST analyses

There are many literature reports on the production of compounds with antimierobial properties by seudomonas spp. Some of these antimicrobial compounds have been identified

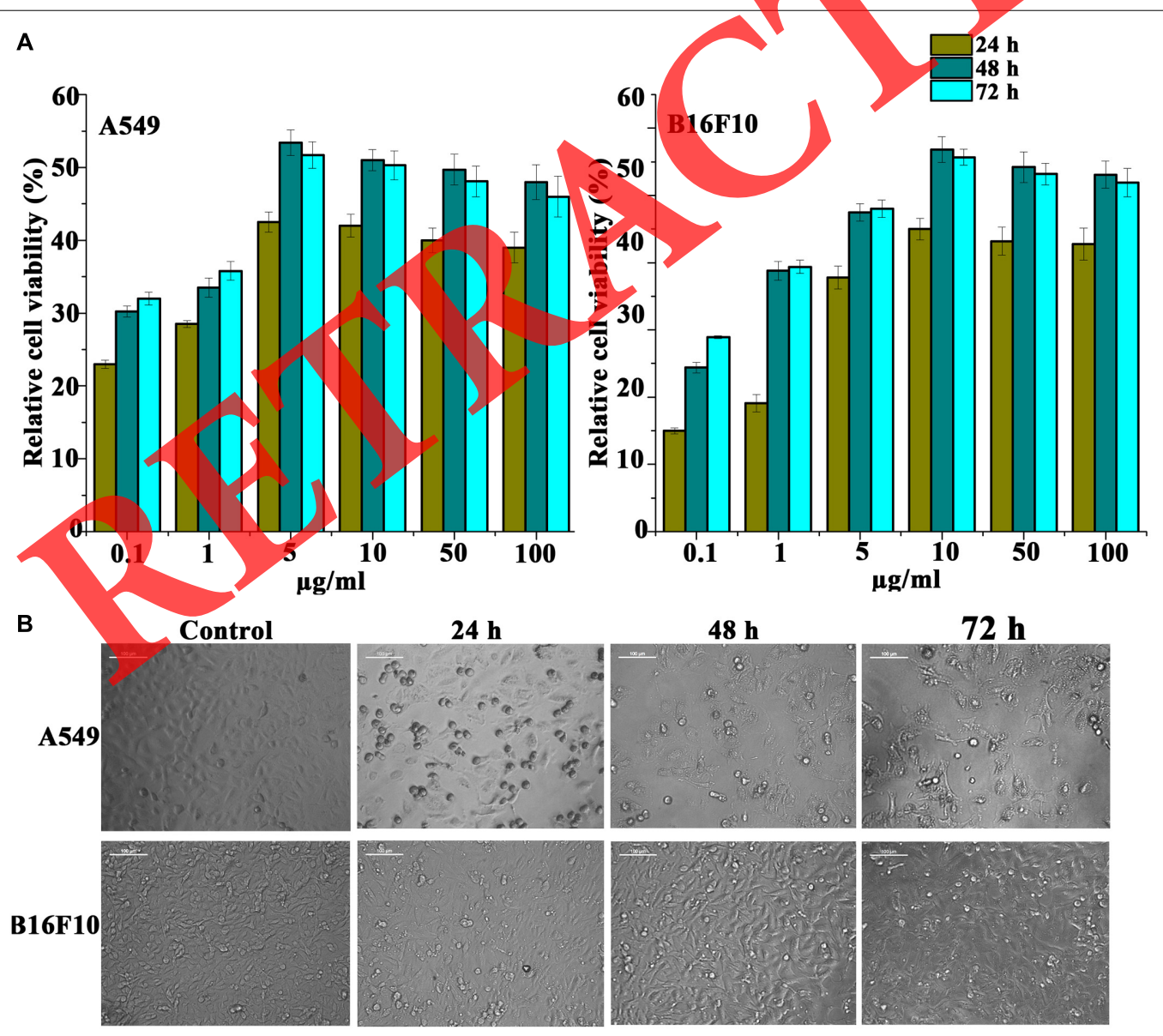

FIGURE 4 | (A) Cytotoxicity profile of Pseudopyronine B on A549 and B16F10 cells measured by MTT assay. (B) Phase contract images of A549 and B16F10 cells treated with Pseudopyronine B. The experiments where performed in three replication and results were expressed as mean \pm standard deviation. 

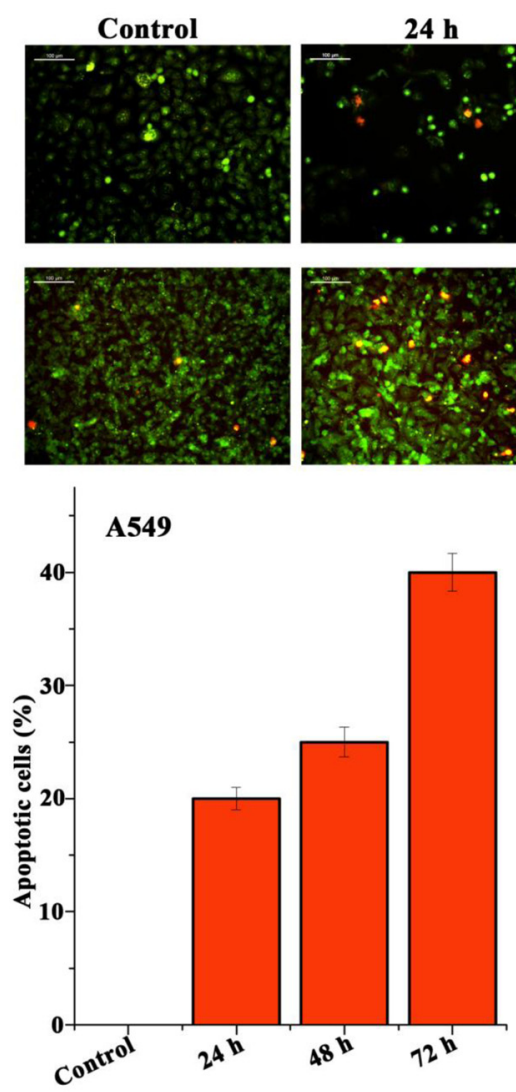

24 h
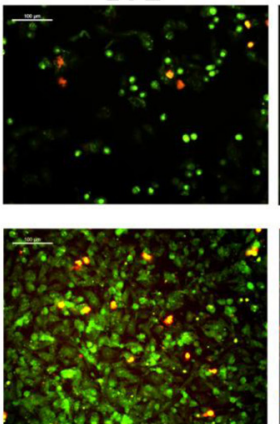

.

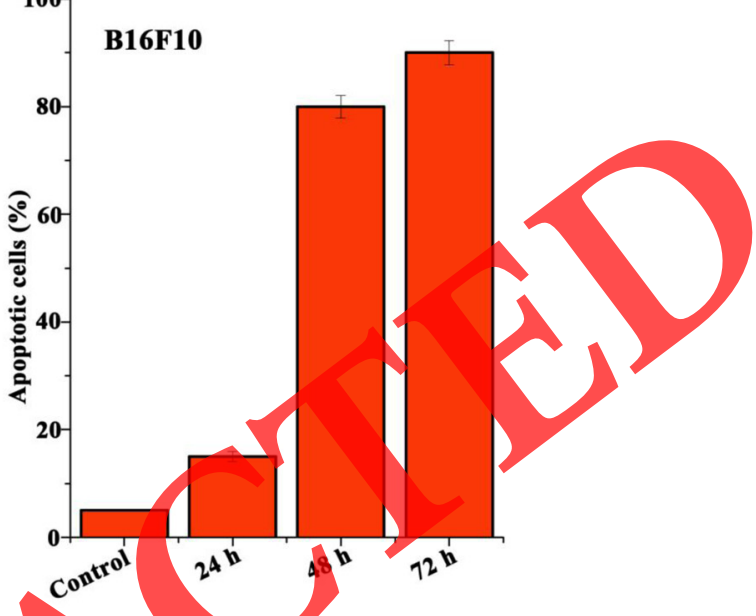

$72 \mathrm{~h}$
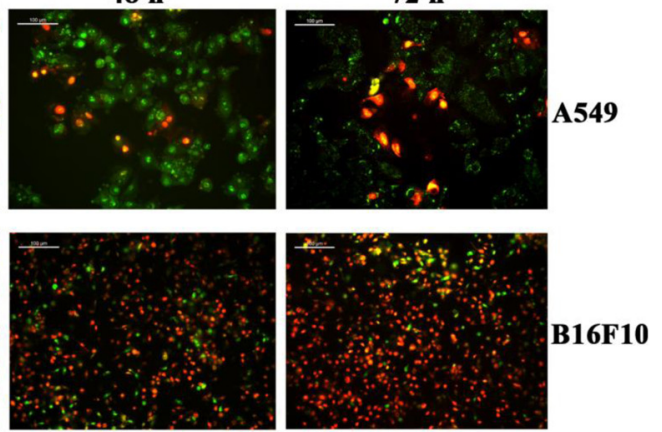

$16 F 10$

FIGURE 5 | Analysis of A549 and B16F10 cell lines to detect apoptosis by detected as green color, whereas the apoptosis cells documented orange-red due of membrane integrity by the action of Pseudopyronine B.

chemically and the structure has been reported (Zhou et al., 2012). Several fluorescent Pseudomonas spp. have currently received world-wide interest due to the production of a board range of bioactive compounds with antibiotics properties such as phenazine-1-carboxylic acid, pyoluteorin, phenazine-1carboxamide, viscosinamide and tesin (Chin-A-Woeng et al., 2003; Hu et al., 2005; Huang et al., 2009) and several bioactive enzymes. In this study, $P$. mosselii exhibit remarkable antimicrobial property especially against a broad range of plant pathogenic fungi, Gram-positive and negative human pathogenic bacteria. So far, many antibiotics have been isolated and identified from Pseudomonas species, and most of them were from $P$. aeruginosa, which is the most studied species of Pseudomonas. P. mosselii is one of the Pseudomonas species that has not been studied extensively. In the present study we have isolated Pseudopyronines B from P. mosselii and the isolation of Pseudopyronine B from $P$. mosselii is reported here for the first time.

The isolation of Pseudopyronines A and B is previously reported from marine sponge associated Pseudomonas species collected from the Fiji islands (Singh et al., 2003, 2011; Kong et al., 2005) and Pseudomonas sp. associated with entomopathogenic nematode (Grundmann et al., 2012). These compounds showed significant MICs against Gram-positive bacteria, including $S$. aureus, B. subtilis, methicillin-resistant $S$. aureus and Enterococcus faecium (MIC value: $2-4 \mu \mathrm{g} / \mathrm{ml}$ ) and reasonable activity against $E$. faecalis and S. pneumoniae (MIC value: 16$64 \mu \mathrm{g} / \mathrm{ml}$ ) with being the more active of the two compounds (Giddens et al., 2008; Singh et al., 2011). Similar results were observed in our study also (Table 1), where in our study also Staphylococcus spp. recorded best activity. Antimycobacterial activity of pseudopyronines against $M$. tuberculosis $\mathrm{H} 37 \mathrm{Rv}$ is also well-reported in the literature (Giddens et al., 2008). Pseudopyronines are powerful and comparatively selective parasitic protozoa (Leishmania donovani) inhibitors (Blunt et al., 2010). These reports clearly portrait the role of Pseudopyronines in modern drug discovery process. The antifungal activity of Pseudopyronines especially Pseudopyronine B is not reported in literature. In the present manuscript the antifungal activity of Pseudopyronine B especially against plant pathogenic fungi is reported for the first time.

Bioactive compounds especially from natural have played a significant role over several years in the growth of various anticancer drugs. Many natural compounds and their derivatives have been successfully categorized according to the standard collection of several cancer drugs, such as paclitaxel, vinblastine, 


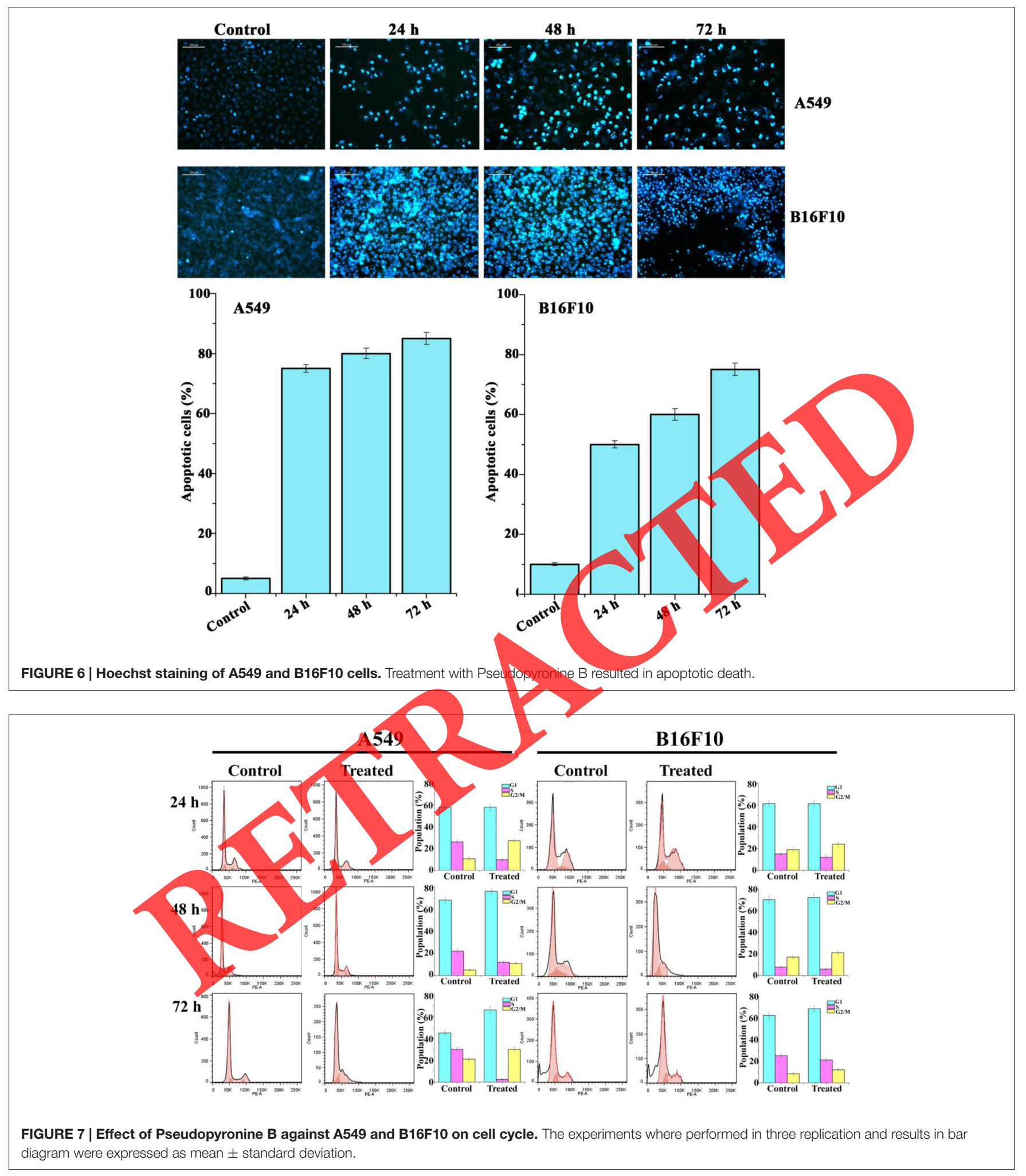

and vincristine (Zhong et al., 2012). Newman et al. (2003) reported that more than $50 \%$ of the novel compounds approved between 1982 and 2002 were derived directly or indirectly from natural compounds. This clearly indicated that natural compound play a profound role in the development of various anticancer drugs. Even though cancer is the leading cause of mortality worldwide and most of the chemotherapeutic compounds already in clinic have been reported to exhibit severe 

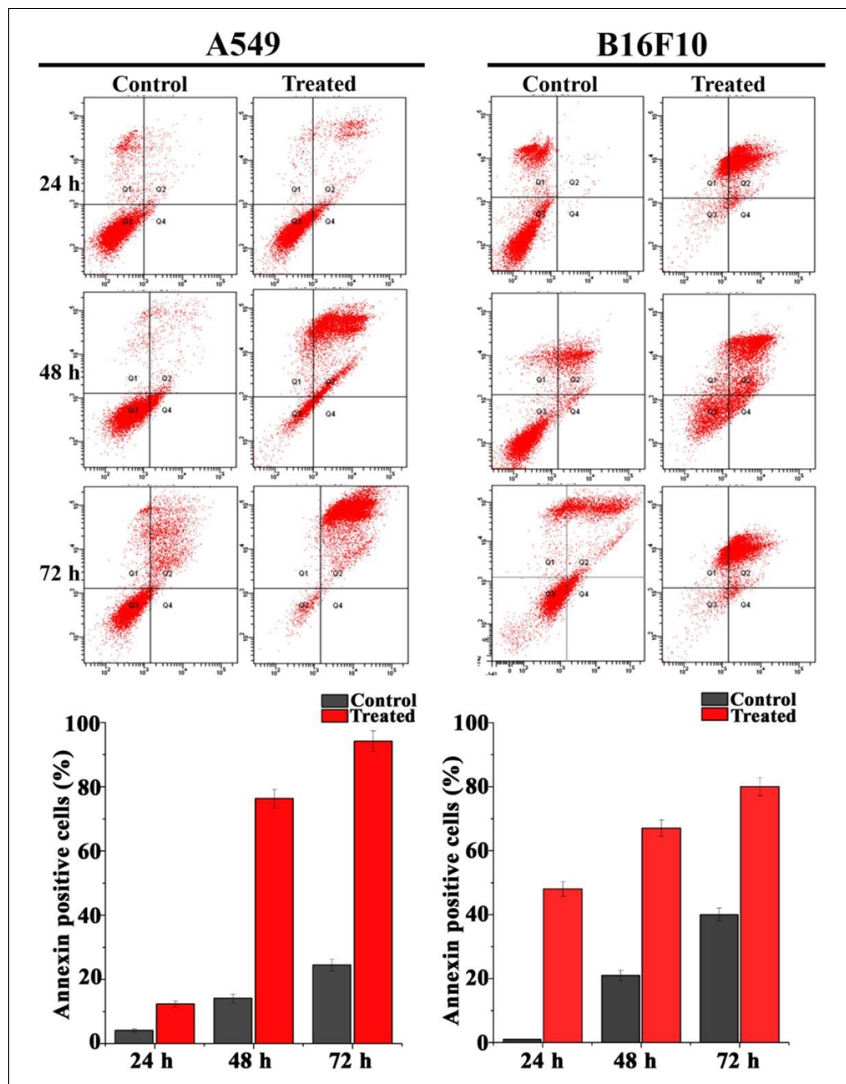

FIGURE 8 | Pseudopyronine B induce phosphatidylserine exposure in A549 and B16F10 cells. The cells were stained with annexin V-FITC and propidium iodide. Analyses were performed by flow cytometry. Each data represents mean $\pm \mathrm{SD}$ from three independent experiments.

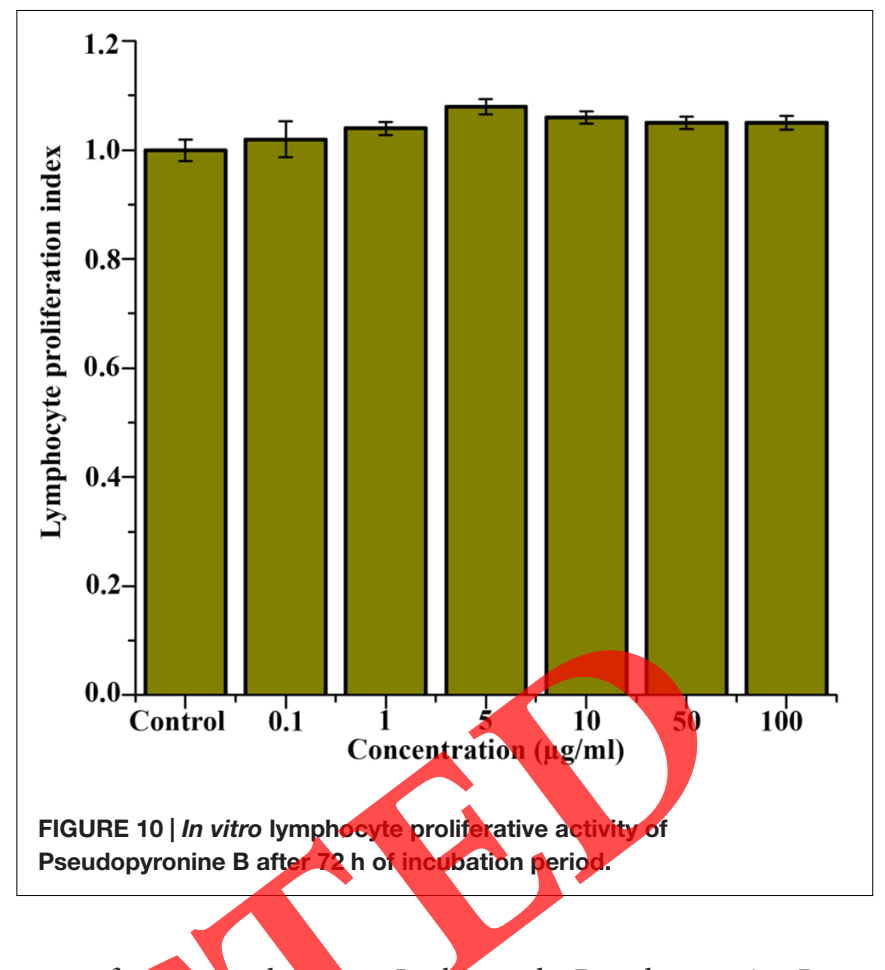

agents from natural sources. In this study, Pseudopyronine B was isolated from natural source and was tested for its cytotoxicity effect on A549, B16F10, and HepG2 cancer cell lines. We showed that Pseudopyronine B effectively inhibited cell growth of A549 and B16F10. When compared to that of A549 and B16F10 cells, Pseudopyronine B treated HepG2 cells recorded less activity. Alterations in the apoptosis and its related signaling pathways have a vital role in the development of tumor (Cao et al., 2010). Pseudopyronine B treated A549a and B16F10 cells exhibited typical morphological features of apoptosis including membrane flip-flop, cell shrinkage, higher uptake of stain with apoptotic markers and finally end up in severe DNA damage. The faults in apoptosis pathway are supposed to be one of the important causes toxicity to normal cells, accompanied by other unwanted side effects to our body. Moreover, most of these compound are highly expensive, mutagenic, and carcinogenic (Cho et al., 2010). Therefore, it is very important to find out low toxic anti-cancer

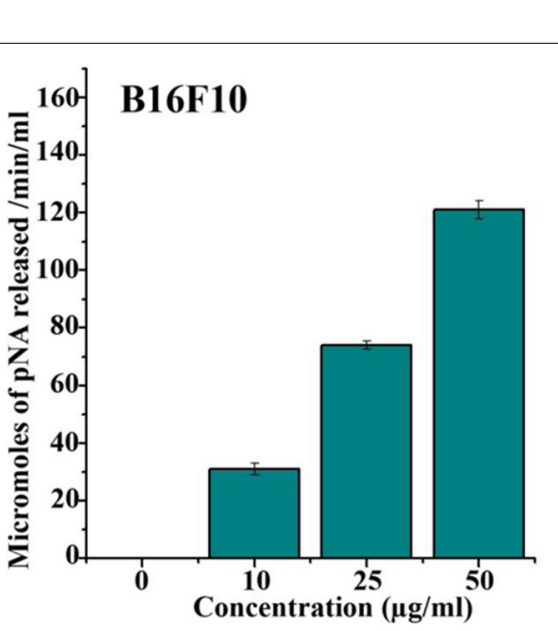

FIGURE 9 | Effect of Pseudopyronine B on the release of caspase 3 in A549 and B16F10 cells. The experiments where performed in three replication and results were expressed as mean \pm standard deviation. 
of human cancer (Thompson, 1995). Thus, a compound which induces apoptosis in cancer cells are one of the most efficient approaches in treating cancer (Lowe and Lin, 2000).

The exact mode of action of Pseudopyronine $\mathrm{B}$ remains unclear. Using acridine orange-ethidium bromide and Hoechst staining assay, we observed that Pseudopyronine B induced apoptosis and DNA damage in A549 and B16F10 cell lines. Interesting in all most all cases, cellular DNA is the major goal of many chemotherapeutic drug molecules, which directly or indirectly attach to DNA. These drugs also obstruct DNA metabolism and inhibit the action of DNA polymerases and/or topoisomerases, which intern inhibit cell replication. Usually apoptosis occurs, following cellular DNA damage. Cysteinecontaining aspartate-specific proteases (caspases) in the cells play a very important role in the activation of various apoptotic signaling pathways. So far, 10 members have been identified in humans. Caspase- 8 and caspase- 9 are two initiator caspases which are capable of transducing apoptosis signals by direct activation of downstream executioner caspase-3 (Chen et al., 2003). Caspase-3, a protein on the common path of cell apoptosis, is one of the most important members and the key executor of cell apoptosis. Caspase-3 usually exists in the cytoplasm in the form of an inactive zymogen. When activated by the many external apoptosis signals, caspase- 3 can induce the inactivation of many key proteases in the cytoplasm, cell nucleus, and cytoskeleton, and finally cause the apoptosis of cells. In the current study, cleavage of caspase-3 and up regulation of its cleaved form in A549 and B16F10 cells treated with Pseudopyronine B revealed Pseudopyronine B-induced apoptosis occurred through the caspase-3-dependent pathway.

Cellular apoptosis (programmed cell death) is a common form of cell death induced by many anticancer compounds/drugs (Vaux and Korsmeyer, 1999). Apoptosis cells are well-categorized by various morphological defects, such as condensation of chromatin, membrane flip-flop, and the formation of apoptotic body. These changes in cancer cells were finally leads to DNA fragmentation which was observed as a ladder on agar gel electrophoresis (Desagher and Martinot, 2000; Xonpunya et al., 2014). Apoptosis is mainly induced by a caspase cascade or translocation of apoptosis inducing factors (Nonpunya et al., 2014). There are two important pathways in the activation of caspase, which are the cell surface death receptor (extrinsic pathway) and mitochondrial initiator (intrinsic pathway). Caspase-3 and caspase-7 is the "execute" caspase for the apoptotic induction, while caspase- 8 and caspase- 9 are the critical caspases and signify the activation of the extrinsic and intrinsic pathways, respectively (McConkey, 1998; Law et al., 2014). The activation of caspases plays a significant role during apoptotic cell death; especially, the caspase 3 activation and activation of this caspase is an important step in the apoptosis procedure (Elmore, 2007). Interestingly Pseudopyronine B recorded enhanced activation of

\section{REFERENCES}

Aravind, S. R., Joseph, M. M., George, S. K., Dileep, K. V., Varghese, S., RoseJames, A., et al. (2015). TRAIL-based tumor sensitizing galactoxyloglucan, a caspase 3, which may play an important role in apoptosis in A549 and B16F10 cells.

\section{CONCLUSION}

Here, it is highly evident from the present findings that a $P$. mosselii which produces a powerful bioactive substance (Pseudopyronine B), active against bacteria especially Grampositive. The present study contributes to the quest for novel antimicrobial compounds, a vital strategy in emerging alternative therapies to treat many infections caused by pathogenic microbes. Pseudopyronine B also recorded significant antifungal activity against plant pathogenic fungi. Isolation of Pseudopyronine B from $P$. mosselii and antifungal activity is reported here for the first time. Although, the present study delivers some valuable basic information about Pseudopyronine B from $P$. mosselii and further detailed investigation are needed to determine their potential for clinical applications.

In the present study, we confirmed that Pseudopyronine B inhibiting cell growth in a dose- and time-dependent manner. We also demonstrated that the cell death is due to apoptosis. To our best knowledge, this is the first investigation reporting the anticancer activity of Pseudopyronine B, which has the potential to be eyaluated as a novel anticancer drug. Further studies are warranted to decipher the molecular mechanisms by which Pseudopyronine B modulates programmed cell death in various cancer cells. More over the results in the present study clearly point out the potential therapeutic property of Pseudopyronine $B$ as an anticancer agent.

\section{AUTHOR CONTRIBUTIONS}

SNK performed experiments, analysis, or interpretation of data and manuscript preparation; SA performed anticancer section; JJ performed purification of compound; GG helped in manuscript preparation; TS performed anticancer section; RL performed purification of compound; BDK designed the work and manuscript correction.

\section{ACKNOWLEDGMENTS}

We thank Director, CSIR-NIIST, and Director RCC for providing necessary facilities to carry out the present work. The authors are also grateful to Kerala State Council for Science Technology and Engineering (KSCSTE), Government of Kerala for financial support in term of PDF fellowship. JJ acknowledges the Department of Science and Technology for providing INSPIRE fellowship (IF 130648). SNK thanks DST-SERB for providing the Young Scientist award.

novel entity for targeting apoptotic machinery. Int. J. Biochem. Cell Biol. 59, 153-166. doi: 10.1016/j.biocel.2014.11.019

Aravind, S. R., Sreelekha, T. T., Dileep Kumar, B. S., Nishanth, K. S., and Mohandas, C. (2014). Characterization of three depside compounds from 
a Western Ghat lichen Parmelia erumpens Kurok with special reference to antimicrobial and anticancer activity. RSC Adv. 4, 34632-34643. doi: 10.1039/C4RA04137B

Arias, C. A., and Murray, B. E. (2009). Antibiotic-resistant bugs in the 21st century-a clinical super-challenge. N. Engl. J. Med. 360, 439-443. doi: 10.1056/NEJMp0804651

Bennani, Y. L. (2012). Drug discovery in the next decade: innovation needed ASAP. Drug Discov. Today 17, S31-S44. doi: 10.1016/j.drudis.2011.12.007

Blunt, J. W., Copp, B. R., Keyzers, R. A., Munro, M. H., and Prinsep, M. R. (2010). Marine natural products. Nat. Prod. Rep. 27, 165-237. doi: 10.1039/b90 $6091 \mathrm{j}$

Bode, H. B., Bethe, B., Hofs, R., and Zeeck, A. (2002). Big effects from small changes: possible ways to explore nature's chemical diversity. Chembiochem 3, 619-627. doi: 10.1002/1439-7633(20020703)3:7<619::AIDCBIC619>3.0.CO;2-9

Cao, W., Li, X. Q., Wang, X., Fan, H. T., Zhang, X. N., Hou, Y., et al. (2010). A novel polysaccharide, isolated from Angelica sinensis (Oliv.) Diels induces the apoptosis of cervical cancer HeLa cells through an intrinsic apoptotic pathway. Phytomed 17, 598-605. doi: 10.1016/j.phymed.2009.12.014

Chen, C. W., Lee, S. T., Wu, W. T., Fu, W. M., Ho, F. M., and Lin, W. W. (2003). Signal transduction for inhibition of inducible nitric oxide synthase and cyclooxygenase-2 induction by capsaicin and related analogs in macrophages. Br. J. Pharmacol. 140, 1077-1087. doi: 10.1038/sj.bjp. 0705533

Chin-A-Woeng, T. F. C., Bloemberg, G. V., and Lugtenberg, B. J. J. (2003). Phenazines and their role in biocontrol by Pseudomonas bacteria. New Phytol. 157, 503-523. doi: 10.1046/j.1469-8137.2003.00686.x

*Clinical, and Laboratory Standards Institute [CLSI] (2008). Reference Method for Broth Dilution Antifungal Susceptibility Testing of Filamentous Fungi, as the Document. is M38-A2. Wayne, PA: Clinical, and Laboratory Standards Institute.

Clinical and Laboratory Standards Institute [CLSI] (2009). Method for antifungal disk diffusion susceptibility testing of yeasts; approved guideline M44-A2, 2nd Edn. Wayne, PA: Clinical and Laboratory Standards Institute.

Clinical and Laboratory Standards Institute [CLSI] (2010). Performance standards for antifungal disk diffusion susceptibility testing of non-dermatophyte filamentous fungi; CLSI document M51-A. (Informational ) supplement 1st Edn. Villanova, PA: Clinical and Laboratory Standards Institute.

Clinical and Laboratory Standards Institute [CLSI] (2012a). Methods for Dilution Antimicrobial Susceptibility Tests for Bacteriathat Grow Aerobically; Approved Standard: CLSI documents M07-A9, 9th Edn. Wayne, PA: Clinical, and Laboratory Standards Institute.

Clinical and Laboratory Standards Institute [CLSI] (2012b). Perforntance standards for antimicrobial disk susceptibility tests; approved standardeleventh edition. CLSI documents M02-AI1. West Valley Road, Suite 2500, Wayne, PA 19087, USA.

Clinical and Laboratory Standards Institute [CLSH (2012c). Reference Method for Broth Dilution Antifungal Susceptibility Testing of Yeasts, as the Document is. (M27)-S4. Wayne, PA: Clinical, and Laboratory Standards Institute.

Cowan, M. M. (1999). Plant products as antimicrobial agents. Clin. Microbiol. Rev. $12,564-582$.

Desagher, S., and Martinou, J. C. (2000). Mitochondria as the central control point of apoptosis. Trends Cell Biol. 10, 369-377. doi: 10.1016/S0962-8924(00) 01803-1

Elmore, S. (2007). Apoptosis: a review of programmed cell death. Toxicol. Pathol. 35, 495-516. doi: 10.1080/01926230701320337

Fadeyi, S. A., Fadeyi, O. O., Adejumo, A. A., Okoro, C. and Myles, E. L. (2013). In vitro anticancer screening of 24 locally used Nigerian medicinal plants. BMC Complem. Alternat. Med. 13:79. doi: 10.1186/1472-6882-13-79

Fischbach, M. A., and Walsh, C. T. (2009). Antibiotics for emerging pathogens. Science 325, 1089-1093. doi: 10.1126/science.1176667

Gao, X., Lu, Y., Xing, Y., Ma, Y., Lu, J., Bao, W., et al. (2012). A novel anticancer and antifungus phenazine derivative from a marine actinomycete BM-17. Microbiol. Res. 167, 616-622. doi: 10.1016/j.micres.2012.02.008

George, E., Kumar, S. N., Nisha, G. V., Bhaskar, B., Morang, P., Ravi, L. S., et al. (2015). Antimicrobial and plant growth promoting activities of a fluorescent Pseudomonas strain PM 105 and its bioactive metabolites. Appl. Biochem. Biotechnol. 176, 529-546. doi: 10.1007/s12010-0151593-3
Giddens, A. C., Nielsen, L., Boshoff, H. I., Tasdemir, D., Perozzo, R., Kaiser, M., et al. (2008). Natural product inhibitors of fatty acid biosynthesis: synthesis of the marine microbial metabolites pseudopyronines A and B and evaluation of their anti-infective activities. Tetrahedron 64, 1242-1249. doi: 10.1016/j.tet.2007.11.075

Graca, A. P., Bondoso, J., Gaspar, H., Xavier, J. R., and Monteiro, M. C. (2013). Antimicrobial activity of heterotrophic bacterial communities from the marine sponge Erylus discophorus (Astrophorida, Geodiidae). PLoS ONE 8:e78992. doi: 10.1371/journal.pone.0078992

Grundmann, F., Dill, V., Dowling, A., Thanwisai, A., Bode, E., Chantratita, N., et al. (2012). Identification and isolation of insecticidal oxazoles from Pseudomonas spp. Beilstein J. Org. Chem. 8, 749-752. doi: 10.3762/bjoc.8.85

Higginbotham, S. J., Arnold, A. E., Ibañez, A., Spadafora, C., Coley, P. D., and Kursar, T. A. (2013). Bioactivity of fungal endophytes as a function of endophyte taxonomy and the taxonomy and distribution of their host plants. PLoS ONE 8:e73192. doi: 10.1371/journal.pone.0073192

Hu, H. B., Xu, Y. Q., Cheng, F., Zhang, X. H., and Hur, B. (2005). Isolation and characterization of a new Pseudomonas strain produced both phenazine 1-carboxylic acid and pyoluteorin. J. Microbiol. Biotechnol. 15, 86-90.

Huang, J., Xu, Y., Zhang, H., Li, Y., Huang, X., and Ren, B. (2009). Temperaturedependent expression of phzM and its regulatory genes lasI and ptsP in rhizosphere isolate Pseudomonas sp. strain M185. Appl. Environ. Microbiol. 75, 6568-6580. doi: 10.1128/AEM.01148-09

Huang, Z., Hu, Y., Shou, L., and Song, M. (2013). Isolation and partial characterization of cyclic lipopeptide antibiotics produced by Paenibacillus ehimensis B7. BMC Microbiol. 13:87. do1:10.1186/1471/2180-13-87

Kong, F., Singh, M. P, and Carter, G. T. (2005). Pseudopyronines A and B, a-pyrones produced by a marine Pseudomonas sp. F92s91, and evidence for the conversion of 4-hydroxy-a-pyrone to 3-furanone. J. Nat. Prod. 68, 920-923. doi: 10.1021/np050038v

Law, C. K. M., Kwok, H. H., Poon, P. Y., Lau, C. C., Jiang, Z. H., Tai, W. C., et al. (2014). Ginsenoside compound K induces apoptosis in nasopharyngeal carcinoma cells via activation of apoptosis inducing factor. Chin. Med. 9:11. doi: $10.1186 / 1749-8546-9-11$

iu, T. Y., Tan, Z. J. Jiang, L., Gu, J. F., Wu, X. S., Cao, Y., et al. (2013). Curcumin duces apoptosis in gallbladder carcinoma cell line GBC-SD cells. Cancer Cell Inter. 13:64. doi: 10.1186/1475-2867-13-64

Lowe, \$. W., and Lin, A. W. (2000). Apoptosis in cancer. Carcinogenesis 21, 485-495. doi: 10.1093/carcin/21.3.485

McConkey, D. J. (1998). Biochemical determinants of apoptosis and necrosis. Toxicol. Lett. 99, 157-168. doi: 10.1016/S0378-4274(98)00155-6

Newman, D. J., Cragg, G. M., and Snader, K. M. (2003). Natural products as sources of new drugs over the period 1981-2002. J. Nat. Prod. 66, 1022-1037. doi: $10.1021 / \mathrm{np} 0300961$

Nonpunya, A., Weerapreeyakul, N., and Barusrux, S. (2014). Cratoxylum formosum (Jack) Dyer ssp. pruniflorum (Kurz) Gogel. (Hóng yá mù) extract induces apoptosis in human hepatocellular carcinoma HepG2 cells through caspase-dependent Pathways. Chin. Med. 9:12. doi: 10.1186/1749-8546-9-12

Payne, D. J., Gwynn, M. N., Holmes, D. J., and Pompliano, D. L. (2006). Drugs for bad bugs: confronting the challenges of antibacterial discovery. Nat. Rev. Drug Discov. 6, 29-40. doi: 10.1038/nrd2201

Saitou, N., and Nei, M. (1987). The neighbor-joining method: a new method for constructing phylogenetic trees. Mol. Biol. Evol. 4, 406-425.

Sambrook, J., Fritsch, E. F., and Maniatis, T. (2001). Molecular Cloning: A Laboratory Manual, 2nd Edn. Vol. I. New York, NY: Cold Spring Harbor, 748.

Singh, M. P., Kong, F., and Janso, J. E. (2003). Novel a-pyrones produced by a marine Pseudomonas sp. F92s91: taxonomy and biological activities. J. Antibiot. (Tokyo). 56, 1033-1044.

Singh, S. B., Young, K., and Miesel, L. (2011). Screening strategies for discovery of antibacterial natural products. Expert Rev. Anti. Infect. Ther. 9, 589-613. doi: 10.1586/eri.11.81

Tamura, K., Dudley, J., Nei, M., and Kumar, S. (2007). MEGA4: molecular evolutionary genetics analysis (MEGA) software version 4.0. Mol. Biol. Evol. 24, 1596-1599. doi: 10.1093/molbev/msm092

Tawiah, A. A., Gbedema, S. Y., Adu, F., Boamah, V. E., and Annan, K. (2012). Antibiotic producing microorganisms from River Wiwi, Lake Bosomtwe and the Gulf of Guinea at Doakor Sea Beach, Ghana. BMC Microbiol. 12:234. doi: $10.1186 / 1471-2180-12-234$ 
Thompson, C. B. (1995). Apoptosis in the pathogenesis and treatment of disease. Science 267, 1456-1462. doi: 10.1126/science.7878464

Vaara, M., Siikanen, O., Apajalahti, J., Fox, J., Frimodt-Møller, N., He, H., et al. (2010). A novel polymyxin derivative that lacks the fatty acid tail and carries only three positive charges has strong synergism with agents excluded by the intact outer membrane. Antimicrob. Agents Chemother. 54, 3341-3346. doi: 10.1128/AAC.01439-09

Vaux, D. L., and Korsmeyer, S. J. (1999). Cell death in development. Cell 96, 245-254. doi: 10.1016/S0092-8674(00)80564-4

Velkov, T., Thompson, P. E., Nation, R. L., and Li, J. (2010). Structure-activity relationships of Polymyxin antibiotics. J. Med. Chem. 53, 1898-1916. doi: $10.1021 / \mathrm{jm} 900999 \mathrm{~h}$

Wang, S., Wang, L., Shi, Z., Zhong, Z., Chen, M., and Wang, Y. (2014). Evodiamine synergizes with doxorubicin in the treatment of chemoresistant human breast cancer without inhibiting P-Glycoprotein. PLoS ONE 9:e97512. doi: 10.1371/journal.pone. 0097512

Zhong, Z., Dang, Y., Yuan, X., Guo, W., Li, Y., Tan, W., et al. (2012). Furanodiene, a natural product, inhibits breast cancer growth both in vitro and in vivo. Cell Physiol. Biochem 30, 778-790. doi: 10.1159/000341457
Zhou, T., Chen, D., Li, C., Sun, Q., Li, L., Liu, F., et al. (2012). Isolation and characterization of Pseudomonas brassicacearum J12 as an antagonist against Ralstonia solanacearum and identification of its antimicrobial components. Microbiol. Res. 167, 388-394. doi: 10.1016/j.micres.2012.01.003

Zin, N. Z., Tasrip, N. A., Desa, M. N. M., Kqueen, C. Y., Zakaria, Z. A., Hamat, R. A., et al. (2011). Characterization and antimicrobial activities of two Streptomyces isolates from soil in the periphery of University Putra Malaysia. Trop. Biomed. $28,651-660$.

Conflict of Interest Statement: The authors declare that the research was conducted in the absence of any commercial or financial relationships that could be construed as a potential conflict of interest.

Copyright (๑) 2016 Nishanth Kumar, Aravind, Jacob, Gopinath, Lankalapalli, Sreelekha and Dileep Kumar. This is an open-access article distributed under the terms of the Creative Commons Attribution License (CC BY). The use, distribution or reproduction in other forums is permitted, provided the original author(s) or licensor are credited and that the original publication in this journal is cited, in accordance with accepted academic practice. No use, distribution or reproduction is permitted which does not comply with these terms.

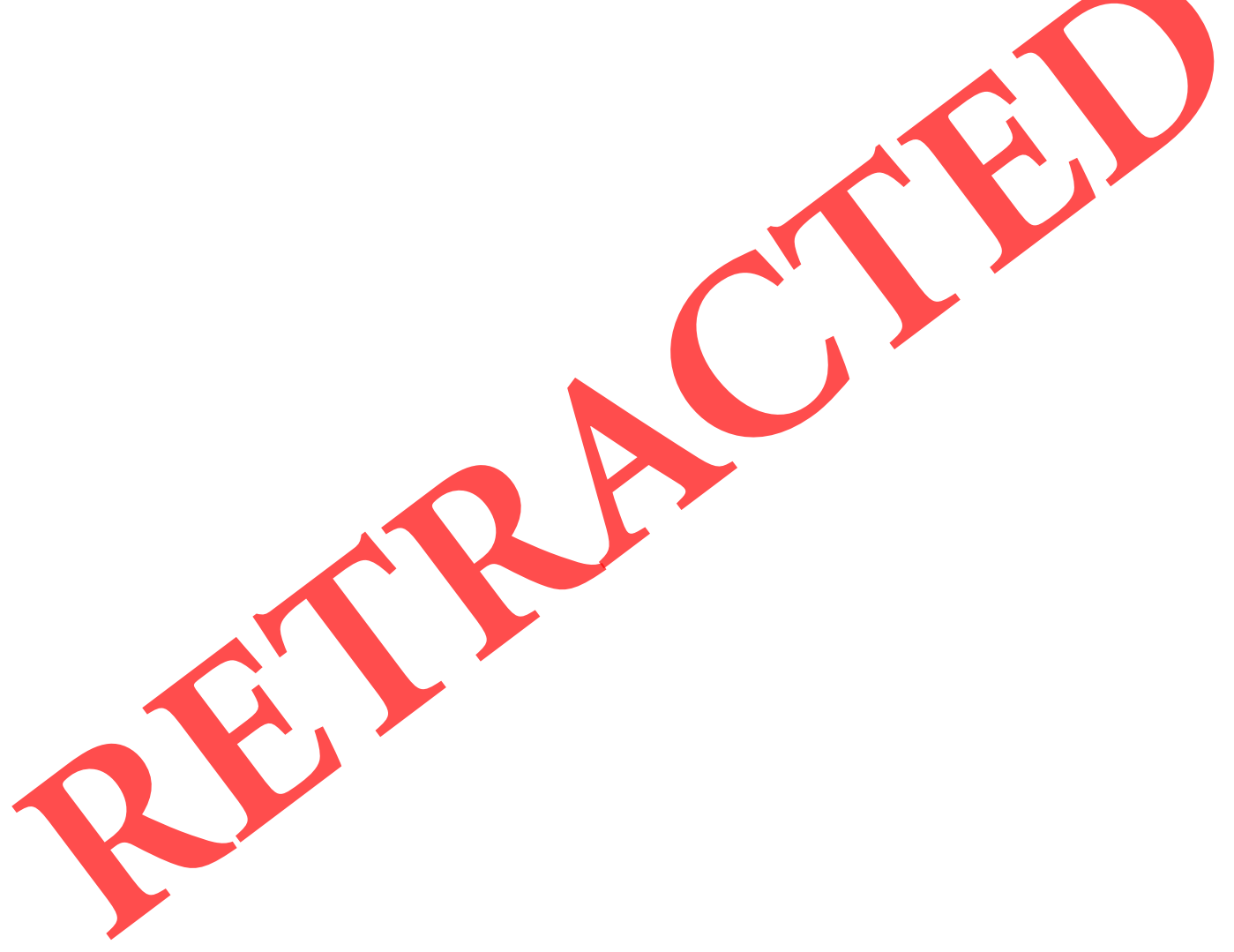

